\title{
Assessment of Photo-Induced Cytotoxic Activity of Cachrys sicula and Cachrys libanotis Enriched-Coumarin Extracts against Human Melanoma Cells
}

\author{
Mariangela Marrelli *(D), Maria Rosaria Perri, Valentina Amodeo, Francesca Giordano (D, Giancarlo A. Statti *, \\ Maria Luisa Panno ${ }^{\dagger}$ and Filomena Conforti $*,+\mathbb{D}$
}

check for updates

Citation: Marrelli, M.; Perri, M.R.; Amodeo, V.; Giordano, F.; Statti, G.A.; Panno, M.L.; Conforti, F. Assessment of Photo-Induced Cytotoxic Activity of Cachrys sicula and Cachrys libanotis Enriched-Coumarin Extracts against Human Melanoma Cells. Plants 2021, 10, 123. https://doi.org/10.3390/ plants10010123

Received: 22 November 2020

Accepted: 3 January 2021

Published: 8 January 2021

Publisher's Note: MDPI stays neutral with regard to jurisdictional clai$\mathrm{ms}$ in published maps and institutional affiliations.

Copyright: (C) 2021 by the authors. Licensee MDPI, Basel, Switzerland. This article is an open access article distributed under the terms and conditions of the Creative Commons Attribution (CC BY) license (https:// creativecommons.org/licenses/by/ $4.0 /)$.
Department of Pharmacy, Health and Nutritional Sciences, University of Calabria, 87036 Rende, Cosenza, Italy; mariarosaria.perri@unical.it (M.R.P.); valentina.amodeo@unical.it (V.A.); francesca.giordano@unical.it (F.G.); mluisa.panno@unical.it (M.L.P.)

* Correspondence: mariangela.marrelli@unical.it (M.M.); giancarlo.statti@unical.it (G.A.S.); filomena.conforti@unical.it (F.C.); Tel.: +39-0984-493168 (M.M. \& F.C.); Fax: +39-0984-493107 (G.A.S.)

+ These authors jointly supervised and equally contributed to this work.

Abstract: Photochemotherapy is one of the most interesting current therapeutic approaches for the treatment of melanoma. Different classes of naturally occurring phytochemicals demonstrated interesting photoactive properties. The aim of this study was to evaluate the photocytotoxic potential of two Cachrys species from Southern Italy: C. sicula and C. libanotis (Apiaceae). The enriched-coumarin extracts were obtained from aerial parts through both traditional maceration and pressurized cyclic solid-liquid (PCSL) extraction using Naviglio extractor ${ }^{\circledR}$. Qualitative and quantitative analyses of furanocoumarins were performed with GC-MS. The photocytotoxic effects were verified on C32 melanoma cells irradiated at a dose of $1.08 \mathrm{~J} / \mathrm{cm}^{2}$. The apoptotic responses were also assessed. Moreover, phenolic content and the in vitro antioxidant potential were estimated. Xanthotoxin, bergapten, and isopimpinellin were identified. All the samples induced concentration-dependent photocytotoxic effects $\left(\mathrm{IC}_{50}\right.$ ranging from 3.16 to $18.18 \mu \mathrm{g} / \mathrm{mL}$ ). The $C$. libanotis sample obtained with Naviglio extractor ${ }^{\circledR}$ was the most effective one $\left(\mathrm{IC}_{50}=3.16 \pm 0.21 \mu \mathrm{g} / \mathrm{mL}\right)$, followed by C. sicula sample obtained with the same technique $\left(\mathrm{IC}_{50}=8.83 \pm 0.20 \mu \mathrm{g} / \mathrm{mL}\right)$. Both Cachrys samples obtained through PCSL induced up-regulation of apoptotic signals such as BAX (Bcl2-associated X protein) and PARP (poly ADP-ribose polymerase) cleavage. Moreover, these samples proved to be more photoactive, giving a greater upregulation of $\mathrm{p} 21$ protein in the presence of UVA radiation. Obtained results suggest that investigated species could be promising candidates for further investigations aimed to find new potential drugs for the photochemotherapy of skin cancer.

Keywords: Apiaceae; Cachrys spp.; furanocoumarins; green extraction technology; photochemotherapy; skin cancer

\section{Introduction}

The World Health Organization (WHO) indicates that cancer is a dominant public health issue with a high mortality rate. Among skin cancer, melanoma is the most aggressive form, with an average of 232,000 new cases/year [1]. It is possible to identify three types of skin cancer, whose names derive from the kind of involved cells: Basal cell carcinoma, squamous cell carcinoma, and malignant melanoma. Basal and squamous types belong to the group of non-melanocytic skin cancer while malignant melanoma is the most aggressive and metastatic type of skin cancer which develops from melanocytes [2].

MAP kinases and phosphatidylinositol-3-kinase (PI3K) are the major signal transduction pathways involved in the development of melanoma. Currently, there are many treatment strategies aiming at blocking the migratory and invasive capacity of cancer cells [3]. The cellular response to most drugs is usually associated with high cell resistance, 
mainly when the diagnosis is late. In this context, the search for natural products for the prevention and treatment of cancer has gained importance, since some phytochemicals have shown proapoptotic and antiangiogenic effects [4].

Natural products, depending on the molecular structure, present different mechanisms of action against tumor cells, such as inhibiting cell proliferation, promoting apoptosis, and inducing autophagy. Flavonoids, a group of biologically active polyphenolic compounds, have been found to play an important role in the inhibition of proliferation and in chemoprevention. Most bioactive flavonoids belong to the classes of flavones $(38.0 \%)$, flavonols (17.5\%), or isoflavonoids (17.5\%) [5]. Different phytochemicals have been shown to possess photosensitizing activity and thereby to exert a greater anti-cancer action, since, during the photochemical reaction, the high production of local ROS directs cancer cells to die through apoptosis and/or necrosis [6].

Other authors have shown that coumarins are especially useful in blocking the growth of rapidly dividing tumoral cells [7].

The molecular studies about these products led to the identification of transductional signals, mainly involved in the regulation of cell survival of breast tumoral cells and targeted by these drugs $[8,9]$.

Anticancer activity on human melanoma cells, due to cytotoxic effects, has been reported for components extracted from Polygonaceae and Asteraceae. Triterpenes and phenolic acids, their main metabolites, seem to be responsible for the cytotoxicity and apoptosis documented in the C32 cell line [10,11].

Similarly, antitumoral activity against human melanoma cells has been demonstrated for extracts from C. pungens Jan from Italy. Different coumarins were identified: The linear furanocoumarins xanthotoxin, bergapten, psoralen, isooxypeucedanin, and isopimpinellin, the angular furanocoumarin columbianetin, the dimethyl-pyranocoumarin jatamansin, and the coumarin 3-methylsuberosine. The methanolic extract, and particularly its chloroform fraction and isolated coumarins fraction, showed strong photocytotoxic activity on UVA irradiated A375 melanoma cells, with $\mathrm{IC}_{50}$ values equal to $0.487 \pm 0.037,0.286 \pm 0.067$, and $0.209 \pm 0.033 \mu \mathrm{g} / \mathrm{mL}$, respectively [12]. So, we focalized our attention on other Cachrys species in order to find new fractions with phototoxic activity against human melanoma cells: C. sicula L. and C. libanotis L.

Cachrys genus (Apiaceae) consists of more than 100 species, and is widely distributed in the Mediterranean basin. Both C. libanotis and C. sicula are widely distributed in Southern Italy. C. libanotis is a perennial plant also present in the South West of Europe and North Africa. It's between $40-80 \mathrm{~cm}$ in height; its leaves are divided into linear strips. Flowers are yellow and organized in umbel. Its fruits are smooth and ovoid $(10-15 \mathrm{~mm})$ and its seeds are extremely acrid. Its roots are gross, white, branching, and aromatic. C. sicula is of 3-15 dm height, the stem is erect, streaked, very branchy, for opposite or verticillated branches, reddened at the base. Its native range is western and central Mediterranean [13]. Very few studies have been carried out on these plants. Some coumarins and ferurol esters have been identified in C. sicula [14]. De Leo and coworkers isolated the three coumarins 8-hydroxymethylpsoralen, sprengelianin, and oxypeucedanin from the dried leaf extract [15]. Palá-Paúl et al. [16] also investigated the chemical composition of the essential oil of $C$. sicula aerial parts and reported the presence of many terpenes, while Pinar [17] isolated the diamine $\mathrm{N}-\mathrm{N}^{\prime}$-di-o-tolylethylendiamine. Some photodermatitis agents have been identified in C. libanotis [18] and the presence of various terpenes have been detected in its essential oil [19].

In this study, we describe the phytochemical fingerprint, the antioxidant potential, and phototoxicity of enriched-coumarin extracts from these two Cachrys species, C. sicula and C. libanotis, obtained by two different extraction processes: Traditional maceration (TM) and pressurized cyclic solid-liquid (PCSL) extraction. This last process has been carried out using the Naviglio extractor ${ }^{\circledR}$, a rapid and innovative solid-liquid dynamic extraction method, which allows us to reduce the extraction times compared to classical maceration $[20,21]$. The mechanism of action of phototoxicity is also described. 


\section{Results}

\subsection{Phytochemical Profile}

In this work, aerial parts of $C$. sicula and C. libanotis species from Southern Italy were extracted with methanol through two different extraction techniques: Traditional maceration (TM) and pressurized cyclic solid-liquid (PCSL) extraction. As regards the raw extracts obtained through PCSL technique, achieved yields were $7.05 \%$ and $12.56 \%$ for C. sicula L. (CSN) and C. libanotis L. (CLN), respectively (Table 1). Higher yields were instead obtained with the classical maceration method: $19.48 \%$ and 17.76 for C. sicula (CSM) and C. libanotis (CLM), respectively.

Table 1. Investigated Cachrys species: Yields and total phenolics and flavonoids.

\begin{tabular}{cccccc}
\hline \multirow{2}{*}{ Sample } & $\begin{array}{c}\text { Extraction } \\
\text { Technique }\end{array}$ & Abbreviation & Yield (\%) & TP $^{\mathbf{1}}$ & TF $^{\mathbf{2}}$ \\
\hline C. sicula L. & Maceration & CSM & 19.48 & $23.1 \pm 0.7^{\mathrm{b}}$ & $0.65 \pm 0.04^{\mathrm{b}}$ \\
& Naviglio $^{\circledR}$ & CSN & 7.05 & $11.4 \pm 0.2^{\mathrm{d}}$ & $0.41 \pm 0.02^{\mathrm{c}}$ \\
C. libanotis L. & Maceration $^{\circledR}$ & CLM & 17.76 & $25.0 \pm 0.2^{\mathrm{a}}$ & $1.29 \pm 0.04^{\mathrm{a}}$ \\
& Naviglio $^{\circledR}$ & CLN & 12.56 & $12.8 \pm 0.1^{\mathrm{c}}$ & $0.09 \pm 0.01^{\mathrm{d}}$ \\
\hline
\end{tabular}

\footnotetext{
${ }^{1}$ Total phenolic content. ${ }^{2}$ Total flavonoid content. Data are expressed as mean $\pm \operatorname{SD}(n=3)$. Results are expressed as $\mathrm{mg}$ of chlorogenic acid (for phenolics) or quercetin equivalent (for flavonoids) per $\mathrm{g}$ of dry plant material. Different letters along columns indicate statistically significant differences at $p<0.05$ (Bonferroni post-hoc test).
}

Total phenolic and total flavonoid contents of Cachrys spp. raw extracts were expressed as equivalents of chlorogenic acid or quercetin per g of dry plant material, respectively. The highest amounts were detected in the extracts obtained through maceration. CLM showed the highest amounts of phenolic compounds $(25.0 \pm 0.2 \mathrm{mg} / \mathrm{g}$, Table 1) and flavonoids $(1.29 \pm 0.04 \mathrm{mg} / \mathrm{g})$, followed by CSM $(23.1 \pm 0.7$ and $0.65 \pm 0.04 \mathrm{mg} / \mathrm{g})$. Lower amounts were observed for the other two samples both for phenolic content (12.8 \pm 0.1 and $11.4 \pm 0.2 \mathrm{mg} / \mathrm{g}$ for CLN and CSN, respectively) and flavonoid content $(0.09 \pm 0.01$ and $0.41 \pm 0.02 \mathrm{mg} / \mathrm{g}$ ).

Samples were then chemically characterized by GC-MS (gas-chromatography coupled to mass spectrometry). Compounds were identified according to their mass spectra and retention times. Eight coumarins were identified (Table 2), including three furanocoumarins: Xanthotoxin, bergapten, and isopimpinellin (Figure 1).

Table 2. Phytochemical composition of Cachrys spp. extracts.

\begin{tabular}{|c|c|c|c|c|c|}
\hline \multirow{2}{*}{ Compound } & \multirow{2}{*}{$\mathbf{R T}^{1}$} & CSM & CSN & CLM & CLN \\
\hline & & \multicolumn{4}{|c|}{$\operatorname{RAP}^{2}$} \\
\hline \multicolumn{6}{|l|}{ Furanocoumarins } \\
\hline Xanthotoxin & 19.154 & 5.3 & 10.8 & 9.1 & 14.8 \\
\hline Bergapten & 19.354 & 1.8 & 2.6 & 2.8 & 2.5 \\
\hline Isopimpinellin & 20.571 & 1.6 & 3.1 & 3.4 & 3.0 \\
\hline \multicolumn{6}{|l|}{ Pyranocoumarins } \\
\hline $\begin{array}{c}\text { Seselin } \\
\text { 2-Methyl-2-butenoic acid }\end{array}$ & 19.462 & - & - & 0.6 & - \\
\hline $\begin{array}{c}\text { 9,10-dihydro-8,8-dimethyl-2-oxo- } 2 \mathrm{H}, 8 \mathrm{H} \text { - } \\
\left.\text { benzo[1,2-b:3,4- } \mathrm{b}^{\prime}\right] \\
\text { dipyran-9-yl ester }\end{array}$ & 24.423 & - & 10.2 & - & 9.7 \\
\hline \multicolumn{6}{|l|}{ Coumarins } \\
\hline Osthol & 19.822 & - & - & 2.8 & - \\
\hline Suberosin & 20.388 & - & - & 2.7 & - \\
\hline Isogeijerin & 21.154 & - & - & 1.2 & 5.6 \\
\hline
\end{tabular}


Table 2. Cont.

\begin{tabular}{cccccc}
\hline Compound & \multirow{2}{*}{$\mathbf{R T}^{\mathbf{1}}$} & $\mathbf{C S M}$ & $\mathbf{C S N}$ & CLM & CLN \\
\cline { 3 - 6 } & & \multicolumn{5}{c}{ RAP $^{2}$} \\
\hline Fatty acids & & & & \\
\hline Myristic acid & 16.496 & - & - & - & 0.2 \\
Palmitic acid & 18.085 & 1.4 & 0.8 & 2.2 & 1.8 \\
$\alpha$-Linolenic acid & 19.897 & - & - & 0.7 & - \\
\hline Terpenes & & & & & - \\
\hline Limonene & 8.506 & $\operatorname{Tr}^{3}$ & 0.2 & - & - \\
Fenchone & 9.603 & - & 0.2 & - & -1 \\
Estragole & 11.141 & 0.2 & 0.8 & 0.1 & - \\
Anethole & 12.284 & - & 0.2 & - & - \\
Neophytadiene & 17.405 & 0.2 & - & - & -
\end{tabular}

${ }^{1}$ Retention time (as min). ${ }^{2}$ Relative area percentage (in TIC $\left.\%\right) . ~{ }^{3}$ Traces $<0.1 \%$.<smiles>COc1c2occc2cc2ccc(=O)oc12</smiles>

Xanthotoxin<smiles>COc1c2ccoc2cc2oc(=O)ccc12</smiles>

Bergapten<smiles>COc1c2ccoc2c(OC)c2oc(=O)ccc12</smiles>

Isopimpinellin

Figure 1. Structure of identified furanocoumarins.

The pyranocoumarin compound 2-methyl-2-butenoic acid 9,10-dihydro-8,8-dimethyl2-oxo-2H,8H-benzo[1,2-b:3,4-b' dipyran-9-yl ester was detected only in the Naviglio extracts (about $10 \%$ of total peak areas), while seselin was identified just in CLM, which also contained three coumarins: osthol, suberosin, and isogeijerin. Moreover, three different fatty acids were recognized, palmitic acid being the major one.

C. sicula also demonstrated a higher content in terpenes: Limonene, fenchone, estragole, anethole, and neophytadiene were identified. On the contrary, estragole was the only compound found in C. libanotis.

Given the importance of furanocoumarins for the phototoxic potential of investigated samples, the quantification of the three psoralens xanthotoxin, bergapten, and isopimpinellin was then accomplished (Table 3).

Table 3. Quantitative analysis of identified furanocoumarins.

\begin{tabular}{ccccc}
\hline \multirow{2}{*}{ Species } & Extract & Xanthotoxin & Bergapten & Isopimpinellin \\
\cline { 2 - 5 } & \multicolumn{4}{c}{$\mathbf{~ m g / m L} \pm$ SD } \\
\hline Cachrys sicula L. & CSM & $2.08 \pm 0.04^{\mathrm{c}}$ & $0.17 \pm 0.01^{\mathrm{b}}$ & $0.27 \pm 0.01^{\mathrm{a}}$ \\
& CSN & $4.10 \pm 0.23^{\mathrm{b}}$ & $0.58 \pm 0.04^{\mathrm{a}}$ & $0.75 \pm 0.03^{\mathrm{a}}$ \\
Cachrys libanotis L. & CLM & $2.23 \pm 0.14^{\mathrm{c}}$ & $0.27 \pm 0.02^{\mathrm{b}}$ & $0.46 \pm 0.04^{\mathrm{a}}$ \\
& CLN & $4.98 \pm 0.21^{\mathrm{a}}$ & $0.59 \pm 0.08^{\mathrm{a}}$ & $0.42 \pm 0.03^{\mathrm{a}}$ \\
\hline
\end{tabular}

Data were expressed as mean \pm SD $(n=3)$. Different letters along each column indicate statistically significant differences at $p<0.05$ (Bonferroni post-hoc test).

Xanthotoxin was the most abundant compound (concentration ranging from 2.08 to $4.98 \mathrm{mg} / \mathrm{mL})$. CLN showed the highest content $(4.98 \pm 0.21 \mathrm{mg} / \mathrm{mL})$, followed by CSN obtained through the same extraction method $(4.10 \pm 0.23 \mathrm{mg} / \mathrm{mL})$, while traditional maceration allowed to reach lower amounts. A similar trend was observed for bergapten, with a higher content in CLN and CSN $(0.59 \pm 0.08$ and $0.58 \pm 0.04 \mathrm{mg} / \mathrm{mL}$, respectively) compared to CLM and CSM $(0.27 \pm 0.02$ and $0.17 \pm 0.01 \mathrm{mg} / \mathrm{mL}, p<0.05$, Bonferroni 
post-hoc test). No statistical differences were detected among samples as regards the isopimpinellin content.

\subsection{Photocytotoxic Activity}

To evaluate the anticancer activity of Cachrys samples on melanoma, C32 cells (human melanoma) were treated with different concentrations of each sample for 30 min of incubation and $1 \mathrm{~h}$ of irradiation, and cell viability was determined after $48 \mathrm{~h}$. All samples from the two Cachrys species, obtained with two extraction methods, affected cell viability in a concentration-dependent manner after irradiation for $1 \mathrm{~h}$ at a dose of $1.08 \mathrm{~J} / \mathrm{cm}^{2}\left(\mathrm{IC}_{50}\right.$ ranging from 3.16 to $18.18 \mu \mathrm{g} / \mathrm{mL}$, Figure 2, Table 4).

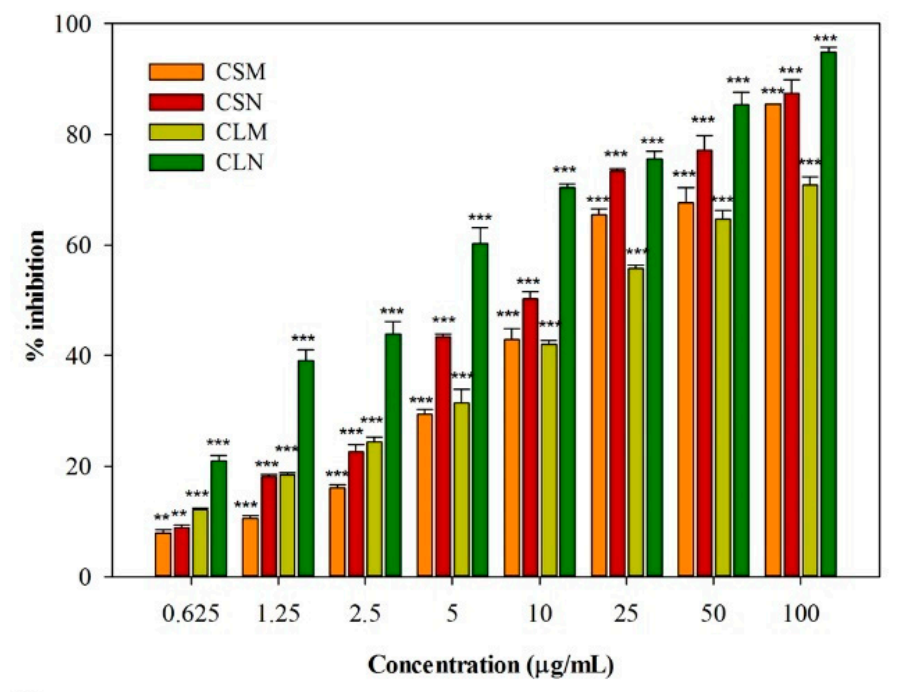

a

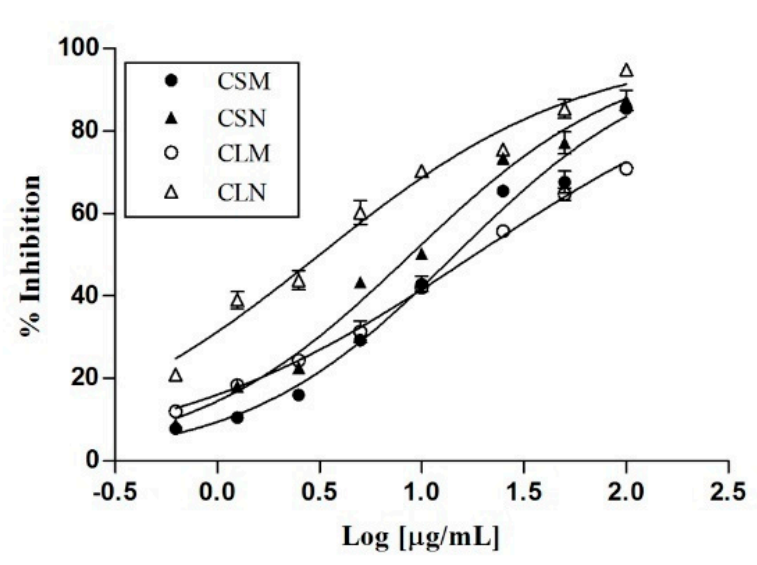

b

Figure 2. (a) Concentration-dependent photocytotoxic effects induced by Cachrys samples. Cells were irradiated for $1 \mathrm{~h}$ at a dose of $1.08 \mathrm{~J} / \mathrm{cm}^{2}$; (b) non-linear regression analyses: CSM, C. sicula L. maceration; CSN, C. sicula L. Naviglio extractor ${ }^{\circledR}$; CLM, C. libanotis L. maceration, CLN, C. libanotis L. Naviglio extractor ${ }^{\circledR}$. Data were expressed as means $\pm \operatorname{SEM}(n=4)$. *** $p<0.001, * * p<0.01$ (Dunnett's test) compared to control (untreated irradiated cells).

Table 4. Photocytotoxicity of Cachrys libanotis L. and Cachrys sicula L. extracts on C32 cells.

\begin{tabular}{cccc}
\hline \multirow{2}{*}{ Species } & \multirow{2}{*}{ Extract } & \multicolumn{2}{c}{ IC $_{\mathbf{5 0}}(\boldsymbol{\mu g} / \mathbf{m L})$} \\
\cline { 3 - 4 } & & Irradiated Cells & Unirradiated Cells \\
\hline Cachrys sicula L. & CSM & $14.57 \pm 0.95^{\mathrm{c}}$ & $>100$ \\
& CSN & $8.83 \pm 0.20^{\mathrm{b}}$ & $26.72 \pm 1.18^{\mathrm{d}}$ \\
Cachrys libanotis L. & CLM & $18.18 \pm 1.33^{\mathrm{c}}$ & $>100$ \\
Bergapten $^{1}$ & CLN & $3.16 \pm 0.21^{\mathrm{a}}$ & $55.20 \pm 1.65^{\mathrm{e}}$ \\
\hline
\end{tabular}

Data were expressed as mean $\pm \operatorname{SEM}(n=4)$. Melanoma cells were pre-treated $(30 \mathrm{~min})$ with samples and then irradiated for $1 \mathrm{~h}$ at a dose of $1.08 \mathrm{~J} / \mathrm{cm}^{2}$. Different letters indicate statistically significant differences at $p<0.05$ (Bonferroni post-hoc test). ${ }^{1}$ Positive control. n.d.: not detectable.

Obtained results showed that the extraction with Naviglio extractor ${ }^{\circledR}$ allowed a better chemical composition for the antitumor activity than the traditional maceration technique. The best activity was observed for CLN sample (C. libanotis Naviglio), with an $\mathrm{IC}_{50}$ of $3.16 \mu \mathrm{g} / \mathrm{mL}$, a very interesting value if compared with the positive control bergapten $\left(p<0.05\right.$, Bonferroni post-hoc test). The $C$. sicula sample obtained with Naviglio extractor ${ }^{\circledR}$ also showed a very good inhibitory activity on cell line viability ( $\mathrm{IC}_{50}=8.83 \pm 0.20 \mu \mathrm{g} / \mathrm{mL}$ ). Even if both these samples, at the highest concentration tested, also induced cytotoxic effects in the dark, the $\mathrm{IC}_{50}$ values observed for unirradiated cells were significantly 
higher than those referred to UVA-treated plates $\left(\mathrm{IC}_{50}\right.$ values equal to $55.20 \pm 1.65$ and $26.72 \pm 1.18 \mu \mathrm{g} / \mathrm{mL}$ for CLN and CSN, respectively). A lower, but still noteworthy, photocytotoxicity was exerted by the two extracts obtained through maceration ( $\mathrm{IC}_{50}$ values of $14.57 \pm 0.95$ and $18.18 \pm 1.33 \mu \mathrm{g} / \mathrm{mL}$, for C. sicula and C. libanotis, respectively), which did not affect cell viability in the dark.

Figure 3 shows cell morphology $48 \mathrm{~h}$ after UVA irradiation as captured on a digital camera. The incubation of cell cultures with a concentration of $25 \mu \mathrm{g} / \mathrm{mL}$ of both C. sicula and C. libanotis PCSL samples and UVA radiation significantly affected cell viability compared to control (untreated irradiated cells).

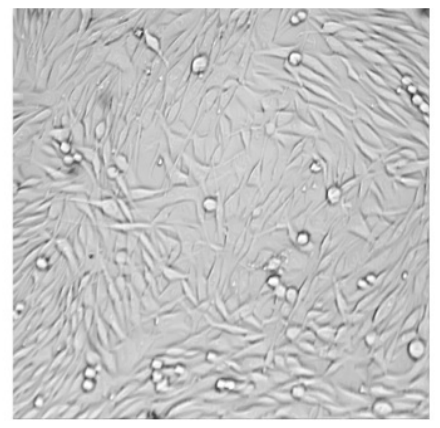

a

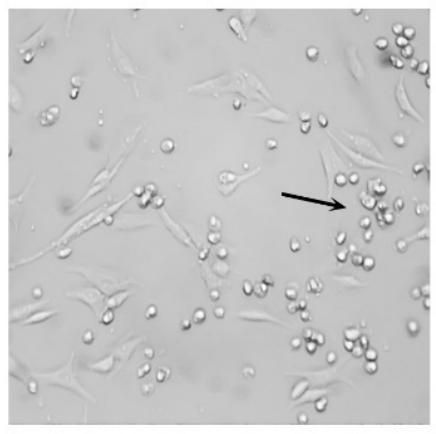

b

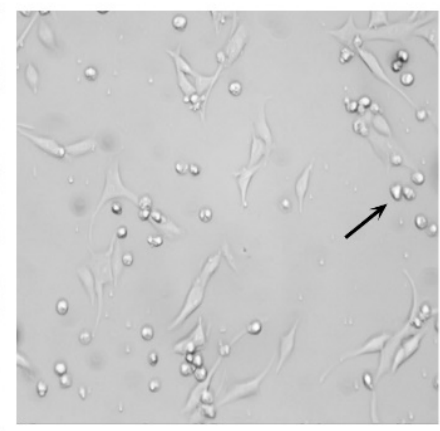

C

Figure 3. C32 cells morphology $48 \mathrm{~h}$ after UVA irradiation at a dose of $1.08 \mathrm{~J} / \mathrm{cm}^{2}$. (a) Control, irradiated cells in RPMI 0.5\% MeOH, without sample; (b) irradiated cells, C. sicula L. obtained with Naviglio extractor ${ }^{\circledR}, 25 \mu \mathrm{g} / \mathrm{mL}$; (c) irradiated cells, C. libanotis L. extracted through Naviglio extractor $^{\circledR}, 25 \mu \mathrm{g} / \mathrm{mL}$. Cells were visualized with an inverted microscope AE20 Motic and images were captured with a VisiCam digital camera. Arrows show cells became rounded and shrunken. Magnification, $10 \times$.

\subsection{Apoptotic Responses on C32 Cells}

The two Cachrys species were also evaluated to assess apoptotic responses on C32 cells. The Naviglio extracts CSN and CLN increase the cyclin-dependent kinase inhibitor p21 protein, with respect to control, with greater up-regulation under the combination with UV. Both CSN and CLN samples stimulate the pro-apoptotic BAX protein. Consistently, PARP (poly ADP-ribose polymerase) signature fragments, biomarkers of cell death, are specifically induced under CSN and CLN, with or without UV exposure (Figure 4).

The other Cachrys samples, CSM and CLM, do not elicit the same results mentioned above. In fact, no increase of p21 protein levels are evidenced in C32 cells that underwent treatment with the maceration products of the Cachrys, and if anything, under UV there is a reduction of the protein with respect to single treatment and control. In contrast, the same treatments cause a significant up-regulation of BAX, the levels of which remain equally high in the presence of co-treatment with UV rays, no significant PARP cleavage is evident under the same experimental conditions (Figure 5). 

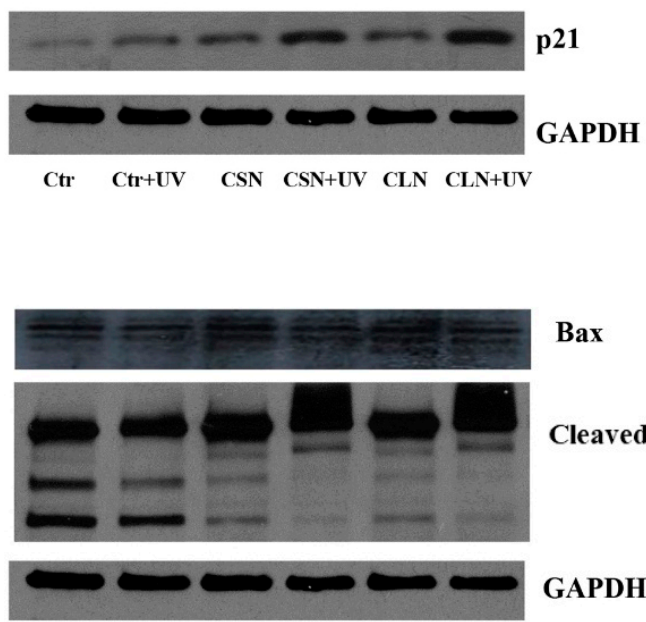

Ctr Ctr+UV CSN CSN+UV CLN $\quad$ CLN+UV

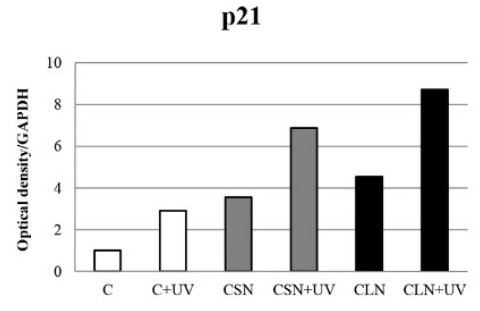

BAX
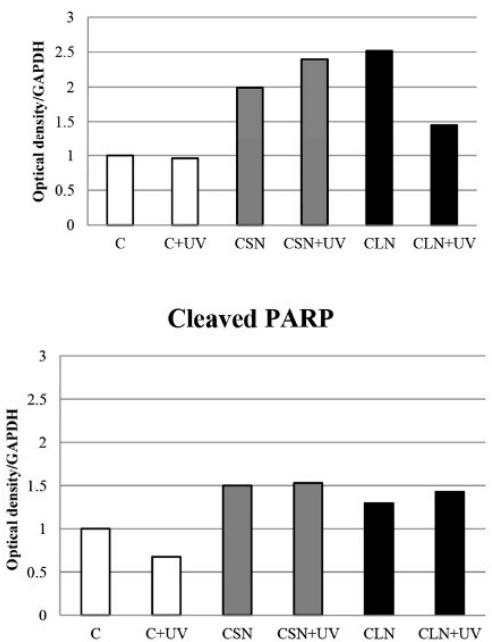

Figure 4. Western Blot analysis of p21, BAX and PARP (poly ADP-ribose polymerase) protein levels in C32 cells treated or not with CSN and CLN extracts for $24 \mathrm{~h}$, both in the presence and absence of UV. The histograms refer to the densitometric analysis (OD) of the Western blot shown in the figure.
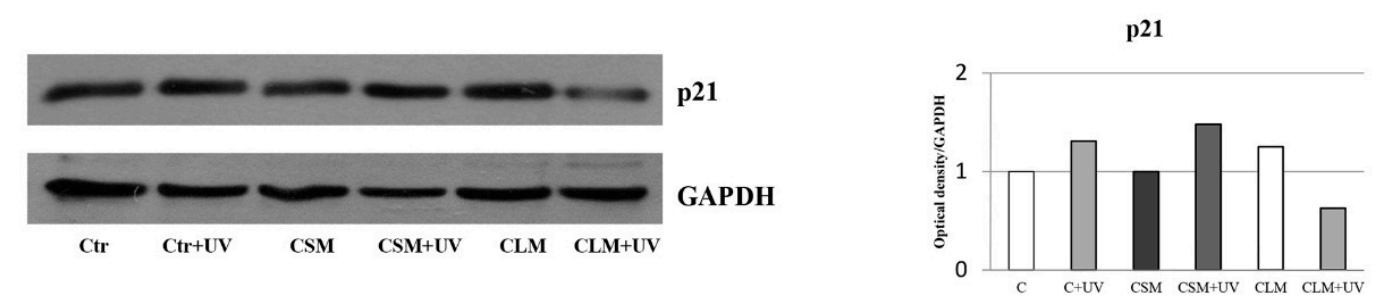

BAX


GAPDH



Figure 5. Western Blot analysis of p21, BAX, and PARP (poly ADP-ribose polymerase) protein levels in C32 cells treated or not with CSM and CLM extracts for $24 \mathrm{~h}$, both in the presence and absence of UV. The histograms refer to the densitometric analysis (OD) of the Western blot shown in the figure. 


\subsection{In Vitro Antioxidant Activity}

Furthermore, the in vitro antioxidant activity of the four Cachrys extracts was evaluated. Two methods were employed: The DPPH and the $\beta$-carotene bleaching test. All the Cachrys samples demonstrated concentration-dependent radical scavenging potency. The two traditional alcoholic macerates $\left(\mathrm{IC}_{50}=102.13 \pm 0.79\right.$ and $112.73 \pm 0.88 \mu \mathrm{g} / \mathrm{mL}$ for CLM and CSM, respectively, Table 5) exerted a better radical scavenging potency than two samples obtained through PCSL extraction $\left(\mathrm{IC}_{50}=163.80 \pm 2.63\right.$ and $212.80 \pm 6.91 \mu \mathrm{g} / \mathrm{mL}$, $p<0.05$, Bonferroni post-hoc test).

Table 5. Antioxidant activity of Cachrys libanotis L. and Cachrys sicula L. extracts.

\begin{tabular}{|c|c|c|c|c|}
\hline \multirow{3}{*}{ Species } & \multirow{3}{*}{ Extract } & \multicolumn{3}{|c|}{$\mathrm{IC}_{50}(\mu \mathrm{g} / \mathrm{mL})$} \\
\hline & & \multirow{2}{*}{ DPPH Test } & \multicolumn{2}{|c|}{$\beta$-Carotene Bleaching Test } \\
\hline & & & $30 \mathrm{~min}$ & $60 \mathrm{~min}$ \\
\hline \multirow[t]{2}{*}{ Cachrys sicula L. } & CSM & $112.73 \pm 0.88^{b}$ & $16.77 \pm 1.43^{b}$ & $31.07 \pm 1.71^{\mathrm{c}}$ \\
\hline & $\mathrm{CSN}$ & $163.80 \pm 2.63^{c}$ & $48.62 \pm 4.05^{\mathrm{d}}$ & $68.55 \pm 2.33^{\mathrm{e}}$ \\
\hline \multirow[t]{2}{*}{ Cachrys libanotis L. } & CLM & $102.13 \pm 0.79^{b}$ & $19.22 \pm 1.07^{b, c}$ & $27.52 \pm 1.73^{c}$ \\
\hline & CLN & $212.80 \pm 6.91^{d}$ & $81.20 \pm 1.52^{\mathrm{f}}$ & $92.44 \pm 1.08 \mathrm{~g}$ \\
\hline Ascorbic acid ${ }^{1}$ & & $2.00 \pm 0.01^{\mathrm{a}}$ & - & - \\
\hline Propyl gallate $^{1}$ & & - & $1.00 \pm 0.02^{\mathrm{a}}$ & $1.00 \pm 0.02^{\mathrm{a}}$ \\
\hline
\end{tabular}

Data were expressed as mean \pm S. E. M. $(n=3)$ Statistically significant differences at $p<0.05$ (Bonferroni post-hoc test) are indicated by different letters along (DPPH) or between columns ( $\beta$ carotene bleaching test). ${ }^{1}$ Positive controls.

The same samples, CLM and CSM, also demonstrated an interesting antioxidant activity in the $\beta$-carotene bleaching method, with $\mathrm{IC}_{50}$ values equal to $16.77 \pm 1.43$ (CSM) and $19.22 \pm 1.07 \mu \mathrm{g} / \mathrm{mL}$ (CLM) after $30 \mathrm{~min}$ of incubation. After $60 \mathrm{~min}$, these extracts were still effective, with $\mathrm{IC}_{50}$ values of $31.07 \pm 1.71$ and $27.52 \pm 1.73 \mu \mathrm{g} / \mathrm{mL}$. The samples obtained though Naviglio extractor ${ }^{\circledR}$ were also effective, even if to a lesser extent.

\section{Discussion}

Among skin cancer with rapid growth, the melanoma represents the most invasive and metastatic one. Due to its strong aggressiveness, there are no effective treatments to antagonize cell growth, and often the cancer cells over time develop resistance to chemotherapy. In patients with metastatic melanoma, several immune therapies have been approved, however, with unsatisfactory responses compared to those obtained with targeted therapies [22].

In this context, more recently, there is the great attention towards natural products since they have been useful in antagonizing chemotherapy resistance as well as they lack major side effects [23].

In the present paper, we investigated the effect of two species of Cachrys (C. sicula and C. libanotis), subjected to different extraction processes, on the apoptotic response of the C32 human melanoma cell line.

In particular, as previously reported, by comparing two methods of extraction on aerial parts of Cachrys, the results indicated that pressurized cyclic solid-liquid (PCSL) extraction yields biologically more active products since they address significant apoptotic effects in C32 cells than the traditional maceration (TM).

The solid-liquid dynamic extractor is an innovative technology of solid-liquid extraction that allows to carry out the extraction in a short time, compared to the other currently used techniques. While most of them are based on osmosis and diffusion principles, PCSL works on Naviglio's Principle, based on an increase of pressure of the extracting liquid on the solid plant material and the generation of a negative gradient pressure from the inside to the outside of the plant matrix $[20,21]$. 
In line with the other results discussed above, the CSN and CLN extracts are able to increase p21 protein, a well-known cyclin-dependent kinase inhibitor (CKI), that is able to affect all cyclin/CDK complexes [24]. Therefore, Cachrys that underwent the PCSL extraction technique is really stronger against C32 cells. In fact, C. libanotis and C. sicula extracted with Naviglio extractor ${ }^{\circledR}$ lead proliferative arrest and up-regulation of apoptotic signals such as BAX and PARP cleavage. In addition, the above extracts are more photosensitive since in the presence of UV rays they give a greater upregulation of $\mathrm{p} 21$, while the increase in BAX and PARP remain equally sustained, like in the absence of photoactivation.

Thus, malignant melanoma C32 cell line was less responsive to apoptotic induction when incubated with Cachrys samples underwent to traditional maceration (TM), than extracts by Naviglio extractor ${ }^{\circledR}$.

These data confirm those of cellular phototoxicity, in which it has been seen that the Naviglio extractor ${ }^{\circledR}$ allows us to obtain a better chemical composition of Cachrys for its antitumor activity. Similarly, gas chromatography-mass spectrometry analyses allowed us to identify eight coumarins, including three furanocoumarins, the class of compounds known for their ability to act as photosensitizers [25]. All the four Cachrys samples were particularly rich in these tricyclic aromatic compounds made of a furan ring fused to a coumarin ( $\alpha$-benzopyrone) system: Xanthotoxin, bergapten, and isopimpinellin were detected, and quantitative analyses were also carried out. The exact molecular mechanism of these compounds relies upon their chemical structure, which in turn depends on the combination of the furan ring and coumarin backbone in an angular or linear structure, and on the number, type, and location of the attached substituents [26]. The $\mathrm{CH}_{3}$ presence at $\mathrm{C5}$ and C8 improves the tumor properties [27]. The C. libanotis extract obtained through PCSL technique using Naviglio extractor ${ }^{\circledR}$ (CLN) showed the highest content of xanthotoxin, $\left(\mathrm{CH}_{3}\right.$ at $\left.\mathrm{C} 8\right)$ followed by $\mathrm{C}$. sicula obtained through the same extraction method.

Samples CLN and CSN also showed a higher content in bergapten $\left(\mathrm{CH}_{3}\right.$ at $\left.\mathrm{C} 5\right)$. No statistical differences were observed among the samples for the isopimpinellin content.

On the contrary, the two Cachrys macerates showed higher amounts of polar constituents. For both Cachrys species, these extracts showed a higher phenolic content compared to the extracts obtained through PCSL technique, with amounts equal to $25.0 \pm 0.2 \mathrm{mg} / \mathrm{g}$ and $23.1 \pm 0.7$ for CLM and CSM, respectively. The same trend was observed for the total flavonoid content.

Consistently, samples obtained through maceration showed a better antioxidant activity, evaluated by the DPPH radical scavenging assay and the $\beta$-carotene bleaching test. Even if all the four Cachrys extracts demonstrated concentration-dependent biological activity, the two alcoholic macerates $\left(\mathrm{IC}_{50}\right.$ values equal to $102.13 \pm 0.79$ and $112.73 \pm 0.88 \mu \mathrm{g} / \mathrm{mL}$ ) exerted a better radical scavenging potency than the other two samples $\left(\mathrm{IC}_{50}=163.80 \pm 2.63\right.$ and $\left.212.80 \pm 6.91 \mu \mathrm{g} / \mathrm{mL}\right)$, and no significant statistical differences were observed among the two species for this kind of activity. The same trend was maintained in the $\beta$-carotene bleaching test, with macerates being significantly more effective than samples realized with PCSL extraction.

In conclusion, the obtained results showed that extraction with the Naviglio extractor ${ }^{\circledR}$ allowed a better chemical composition for the antitumor activity than the traditional maceration technique, and suggest that the investigated species could be promising candidates for further studies with the aim to find new potential drugs useful in the photochemotherapy of skin cancer. Furanocoumarins, probably, are the compounds directly involved in this activity, but the most important aspect is how these compounds are present together in the tested sample showing a high activity.

\section{Materials and Methods}

4.1. Reagents

Chlorogenic acid, ascorbic acid, Folin-Ciocalteu reagent, 2,2-diphenyl-1-picrylhydrazyl (DPPH), $\beta$-carotene, linoleic acid, Tween 20, fetal bovine serum (FBS), L-glutamine, peni- 
cillin/streptomycin, RPMI-1640 medium, trypan blue, phosphate buffered saline (PBS), Hanks' Balanced Salt Solution, 3-(4,5-dimethylthiazol-2-yl)-2,5-diphenyltetrazolium bromide (MTT), and reference compounds were obtained from Sigma-Aldrich S.p.a. (Milano, Italy). Melanoma C32 cells were obtained from Type Culture Collection (ATCC) no. CRL1585. p21, Bax, PARP, GAPDH, and peroxidase-coupled goat anti-mouse or goat anti-rabbit antibodies were obtained from Santa Cruz Biotechnology (Heidelberg, Germany); ECL System (Amersham Pharmacia Biotech, Cologno Monzese, Italy). All other reagents, were supplied by VWR International s.r.l. (Milan, Italy).

\subsection{Plant Materials and Extraction Procedures}

The aerial parts of C. sicula and C. libanotis were collected in Southern Italy. Plants were identified by Filomena Conforti, and a voucher specimen has been deposited at the Herbarium of natural History Museum of Calabria. The air-dried aerial parts of C. sicula and C. libanotis were extracted with methanol through maceration $(72 \mathrm{~h} \times 3$ times, plant to solvent ratio $1: 10 \mathrm{~g} / \mathrm{mL}$ ) and also by means of Naviglio extractor ${ }^{\circledR}$ (Atlas Filtri SrL, Limena, PD, Italy) (plant:solvent ratio 1:10 g/mL $\times 2$ cycles). Obtained total extracts (CSM and CLM for samples obtained with maceration; CSN and CLN for samples obtained with Naviglio) were concentrated under reduced pressure at $40{ }^{\circ} \mathrm{C}$. The extracts were dried, weighed, and stored at $4{ }^{\circ} \mathrm{C}$ for experimental use.

\subsection{Determination of Total Phenolic and Flavonoid Content}

The total phenolic content was determined using the Folin-Ciocalteu method [28]. Briefly, $50 \mathrm{mg}$ of the extracts were dissolved in $25.0 \mathrm{~mL}$ of an extraction solution (acetone: methanol: water: acetic acid, 40:40:20:0.1) and heated for $1 \mathrm{~h}$ at $60^{\circ} \mathrm{C}$. Then $200 \mu \mathrm{L}$ of samples, $1.0 \mathrm{~mL}$ of Folin-Ciocalteu's reagent and $1.0 \mathrm{~mL}$ of sodium carbonate $(7.5 \%)$ were mixed and absorbance was measured at $726 \mathrm{~nm} 2 \mathrm{~h}$ later. The total phenolics content was calculated from the calibration curve, and the results were expressed as mg of chlorogenic acid equivalents per $\mathrm{g}$ of dried plant material.

The total flavonoid content of extracts was determined by a colorimetric method based on the use of aluminum chloride [29]. One $\mathrm{mL}$ of each extract $(2 \mathrm{mg} / \mathrm{mL}$ in $80 \% \mathrm{EtOH})$ was added to $1 \mathrm{~mL}$ of $2 \% \mathrm{AlCl}_{3}$. The absorbance was measured at $430 \mathrm{~nm} 15$ min later. Results were calculated from calibration curve of the standard quercetin, and data were reported as $\mathrm{mg}$ of standard equivalent per $\mathrm{g}$ of dry plant material.

\subsection{GC-MS Analysis}

The coumarins, terpenes, and fatty acids content was assessed by means of gas chromatography-mass spectrometry (GC-MS). Qualitative GC-MS analyses were carried out using a gas chromatograph (Hewlett-Packard 6890) equipped with an SE-30 capillary column coupled to a selective mass detector (Hewlett-Packard 5973). Helium was utilized as the carrier gas, and a programmed temperature from 60 to $280^{\circ} \mathrm{C}$ (with a rate of $16^{\circ} / \mathrm{min}$ ) was used to realize the analyses. The injector and detector were set, respectively, at $250^{\circ}$ and $280{ }^{\circ} \mathrm{C}$ [30]. Compounds were identified by comparing the GC retention factors with those of standards and the mass spectra with the Wiley 138 library data.

Quantitative GC analyses were performed to determine the content of furanocoumarins xanthotoxin, bergapten, and isopimpinellin in the extracts. Bergapten $(10-0.16 \mathrm{mg} / \mathrm{mL}$ in $\mathrm{MeOH} / \mathrm{CHCl}_{3}$ ) was used as the external standard, and the linear regression equation was

$$
y=1 E+07 x+2 E+06\left(R^{2}=0.9949\right)
$$

$1 \mu \mathrm{L}$ of each tested extract was injected in the GC-MS system at a final concentration of $50 \mathrm{mg} / \mathrm{mL}$. All the analyses were carried out in isothermal conditions at $235^{\circ} \mathrm{C}$, and GC peaks area was determined in triplicate. 


\subsection{Cellular Phototoxicity}

The photocytotoxic activity was determined as earlier described [31]. Human melanoma cells (C32) were grown in RPMI-1640 medium supplemented with L-glutamine, penicillin/streptomycin, and fetal bovine serum $(1 \%, 1 \%$, and $10 \%$, respectively). For the experiments, $100 \mu \mathrm{L}$ of medium containing $3.8 \times 10^{4}$ cells were placed in each well of a 96-well tissue culture microtiter plate. After $24 \mathrm{~h}$ incubation, the medium was removed and $100 \mu \mathrm{L}$ of samples $(0.625-100 \mu \mathrm{g} / \mathrm{mL})$, dissolved in $\mathrm{MeOH}$ and diluted with Hanks Balanced Salt Solution (HBSS, pH 7.2), were added to each well. Plates were incubated at $37^{\circ} \mathrm{C}$ for $30 \mathrm{~min}$ and then irradiated. UV irradiation was carried out at $365 \mathrm{~nm}$ with an HPW 125 Philips lamp. The spectral irradiance of the source was $0.3 \mathrm{~mW} \mathrm{~cm}^{-2}$ as measured by a radiometer equipped with a 365-CX sensor (Cole-Parmer Instrument Company, Niles, IL, USA). Cells were irradiated for $1 \mathrm{~h}$ at a dose of $1.08 \mathrm{~J} / \mathrm{cm}^{2}$. To prevent contamination from other light sources, the assay was performed in a dark room. Then, the solution was replaced with new medium, and microtiter plates were incubated for further $48 \mathrm{~h}$. Bergapten was used as positive control.

Cytotoxicity was evaluated using the 3-[4,5-dimethyl-2-yl]-2,5-diphenyl tetrazolium bromide (MTT) assay [32]. Cell morphology was visualized after and without irradiation with an inverted microscope (AE20 Motic, Motic Instruments, Inc., VWR, Milano, Italy), and images were captured with a digital camera (VisiCam 3.0 USB, VWR, Milano, Italy).

\subsection{Immunoblotting Analysis}

The melanoma cells (C32) were harvested and lysed in $500 \mu \mathrm{L}$ of RIPA buffer for total protein extraction. A 10\% SDS-polyacrylamide gel was used for the resolution of the proteins that were transferred to a nitrocellulose membrane. Then, the filter was probed with p21, BAX, PARP, and GAPDH antibodies (Santa Cruz, Biotechnology, Heidelberg, Germany). The antibody antigen complex was detected with a secondary antibody conjugated to horseradish peroxidase and revealed with the ECL System (Amersham Pharmacia Biotech, Cologno Monzese, Italy) [33].

\subsection{Free Radical Scavenging Activity (FRSA) Assay}

The hydrogen atom or electron-donation ability of the extracts was evaluated based on the bleaching of a purple solution of 1,1-diphenyl-2-picryl-hydrazyl (DPPH), as earlier described [34]. Briefly, $200 \mu \mathrm{L}$ of each extract $(5-1000 \mu \mathrm{g} / \mathrm{mL})$ were added to $800 \mu \mathrm{L}$ of a $0.1 \mathrm{mM}$ solution of DPPH and incubated in the dark. The absorbance was measured at $517 \mathrm{~nm} 30 \mathrm{~min}$ later. Ascorbic acid was used as a positive control.

\section{8. $\beta$-Carotene-Linoleate Bleaching Assay}

Antioxidant activity was determined using the $\beta$-carotene bleaching method [35]. $\beta$-carotene $(0.2 \mathrm{mg}$ in $1 \mathrm{~mL}$ chloroform $)$ was added to $0.02 \mathrm{~mL}$ of linoleic acid and $0.2 \mathrm{~mL}$ of $100 \%$ Tween 20 . Chloroform was removed and $100 \mathrm{~mL}$ of water were added. Then, $5 \mathrm{~mL}$ of the emulsion were added to $0.2 \mathrm{~mL}$ of samples in methanol (concentrations ranging from 0.25 to $100 \mu \mathrm{g} / \mathrm{mL}$ ) and placed in a water bath at $45^{\circ} \mathrm{C}$ for $60 \mathrm{~min}$. Propyl gallate was used as standard. The absorbance was measured at $470 \mathrm{~nm}$ at the initial time and after 30 and $60 \mathrm{~min}$. The antioxidant activity was measured in terms of the successful prevention of $\beta$-carotene bleaching.

\subsection{Statistical Analysis}

Experiments involving cell lines were carried out in quadruplicate, while the other assays were run in triplicate. Results were expressed as means \pm SEM. Data were checked for normality and homogeneity of variances (D'Agostino-Pearson's K2 test and Levene's test, respectively). Biological data were fitted through nonlinear regression in order to calculate the $\mathrm{IC}_{50}$ values using GraphPad Prism Software (San Diego, CA, USA).

Statistical differences between treated groups and the control were estimated by one-way analysis of variance (ANOVA) followed by Dunnett's multiple comparison test, 
while the statistical significance of differences among treated group means were tested by Bonferroni post-hoc test $(p \leq 0.05)$.

Author Contributions: Phytochemical investigation, M.M. and M.R.P.; biological investigation, M.M., V.A. and F.G., data curation, M.M. and F.G.; writing-original draft preparation, M.M. and F.G.; writing—review and editing, G.A.S., M.L.P. and F.C.; supervision, G.A.S., M.L.P. and F.C. All authors have read and agreed to the published version of the manuscript.

Funding: M. R. Perri was supported by POR Calabria FESR/FSE 2014-2020.

Institutional Review Board Statement: Not applicable.

Informed Consent Statement: Not applicable.

Data Availability Statement: The data presented in this study are available on request from the corresponding authors.

Conflicts of Interest: The authors declare no conflict of interest.

$\begin{array}{ll}\text { Abbreviations } \\ \text { CSM } & \text { Cachrys sicula extracted through maceration } \\ \text { CSN } & \text { Cachrys sicula extracted with Naviglio extractor } \\ \text { CLM } & \text { Cachrys libanotis extracted through maceration } \\ \text { CLN } & \text { Cachrys libanotis extracted with Naviglio extractor }{ }^{\circledR} \\ \text { PCSL } & \text { Pressurized cyclic solid-liquid extraction } \\ \text { TM } & \text { Traditional maceration }\end{array}$

\section{References}

1. Albuquerque, K.R.S.A.; Pacheco, N.M.; del Rosario Loyo Casao, T.; de Melo, F.C.S.A.; Novaes, R.D.; Gonçalves, R.V. Applicability of plant extracts in preclinical studies of melanoma: A systematic review. Mediat. Inflamm. 2018, 6797924. [CrossRef] [PubMed]

2. Russo, A.; Cardile, V.; Graziano, A.C.E.; Avola, R.; Montenegro, I.; Cuellar, M.; Villena, J.; Madrid, A. Antigrowth activity and induction of apoptosis in human melanoma cells by Drymis winteri forst extract and its active components. Chem. Biol. Interact. 2019, 25, 79-85. [CrossRef] [PubMed]

3. AlQathama, A.; Prieto, J.M. Natural products with therapeutic potential in melanoma metastasis. Nat. Prod. Rep. 2015, 32, 1170-1182. [CrossRef] [PubMed]

4. Chinembiri, T.; du Plessis, L.; Gerber, M.; Hamman, J.; du Plessis, J. Review of natural compounds for potential skin cancer treatment. Molecules 2014, 19, 11679-11721. [CrossRef] [PubMed]

5. De Oliveira Júnior, R.G.; Ferraz, C.A.A.; Silva, M.G.; de Lavor, É.M.; Rolim, L.A.; de Lima, J.T.; Fleury, A.; Picot, L.; de Souza Siqueira Quintans, J.; Quintans Junior, L.J.; et al. Flavonoids: Promising natural products for treatment of skin cancer (melanoma). In Natural Products and Cancer Drug Discovery; Badria, F.A., Ed.; InTech: Rijeka, Croatia, 2017; pp. 161-210.

6. Mansoori, B.; Mohammadi, A.; Doustvandi, M.A.; Mohammadnejad, F.; Kamari, F.; Gjerstorff, M.F.; Baradaran, B.; Hamblin, M.R. Photodynamic therapy for cancer: Role of natural products. Photodiagnosis Photodyn. Ther. 2019, 26, 395-404. [CrossRef]

7. Panno, M.L.; Giordano, F. Effects of psoralens as anti-tumoral agents in breast cancer cells. World J. Clin. Oncol. 2014, 5, 348-358. [CrossRef]

8. Panno, M.L.; Giordano, F.; Palma, M.G.; Bartella, V.; Rago, V.; Maggiolini, M.; Sisci, D.; Lanzino, M.; De Amicis, F.; Andò, S. Evidence that bergapten, independently of its photoactivation, enhances p53 gene expression and induces apoptosis in human breast cancer cells. Curr. Cancer Drug Targets 2009, 9, 469-481. [CrossRef]

9. Panno, M.L.; Giordano, F.; Mastroianni, F.; Palma, M.G.; Bartella, V.; Carpino, A.; Aquila, S.; Andò, S. Breast cancer cell survival signal is affected by bergapten combined with an ultraviolet irradiation. FEBS Lett. 2010, 584, 2321-2326. [CrossRef]

10. Nawrot-Hadzik, I.; Choromańska, A.; Abel, R.; Preissner, R.; Saczko, J.; Matkowski, A.; Hadzik, J. Cytotoxic effect of vanicosides $\mathrm{A}$ and B from Reynoutria sachalinensis against melanotic and amelanotic melanoma cell lines and in silico evaluation for inhibition of BRAFV600E and MEK1. Int. J. Mol. Sci. 2020, 21, 4611. [CrossRef]

11. Strzemski, M.; Wojnicki, K.; Sowa, I.; Wojas-Krawczyk, K.; Krawczyk, P.; Kocjan, R.; Such, J.; Latalski, M.; Wnorowski, A.; Wójciak-Kosior, M. In vitro antiproliferative activity of extracts of Carlina acaulis subsp. caulescens and Carlina acanthifolia subsp. utzka. Front. Pharmacol. 2017, 8, 371. [CrossRef]

12. Menichini, G.; Alfano, C.; Provenzano, E.; Marrelli, M.; Statti, G.A.; Menichini, F.; Conforti, F. Cachrys pungens Jan inhibits human melanoma cell proliferation through photo-induced cytotoxic activity. Cell Prolif. 2012, 45, 39-47. [CrossRef] [PubMed]

13. Pignatti, S. Flora d'Italia, 1st ed.; Edagricole: Bologna, Italy, 1982.

14. Grande, M.; Aguado, M.T.; Mancheño, B.; Piera, F. Coumarins and ferulol esters from Cachrys sicula. Phytochemistry 1986, 25, 505-507. [CrossRef] 
15. Le Leo, M.; D’Ambola, M.; Germanò, M.P.; Venturella, F. Coumarins from Cachrys sicula L. Pharmacologyonline 2017, 2, $213-217$.

16. Palá-Paúl, J.; Velasco-Negueruela, A.; Perez-Alonso, M.J.; Sanz, J. Essential oil composition of the aerial parts of Cachrys sicula L. Flavour Fragr. J. 2002, 17, 64-68. [CrossRef]

17. Pinar, M.; Alemany, A. N-N'-di-o-tolylethylendiamine from Cachrys sicula. Phytochemistry 1975, 14, 313-314. [CrossRef]

18. Ena, P.; Cerri, R.; Dessi, G.; Manconi, P.M.; Atzei, A.D. Phototoxicity due to Cachrys libanotis. Contact Dermat. 1991, 24, 1-5. [CrossRef]

19. Bouderdara, N.; Elomri, A.; Djarri, L.; Medjroubi, K.; Seguin, E.; Verite, P. Chemical composition of the essential oil of Cachrys libanotis from Algeria. Nat. Prod. Commun. 2011, 6, 115-117. [CrossRef]

20. Naviglio, D. Naviglio's principle and presentation of an innovative solid-liquid extraction technology: Extractor Naviglio ${ }^{\circledR}$. Anal. Lett. 2003, 36, 1647-1659. [CrossRef]

21. Naviglio, D.; Pizzolongo, F.; Romano, R.; Ferrara, L.; Naviglio, B.; Santini, A. An innovative solid-liquid extraction technology: Use of the Naviglio Extractor for the production of lemon liquor. Afr. J. Food Sci. 2007, 1, 042-050.

22. Luke, J.J.; Flaherty, K.T.; Ribas, A.; Long, G.V. Targeted agents and immunotherapies: Optimizing outcomes in melanoma. Nat. Rev. Clin. Oncol. 2017, 14, 463-482. [CrossRef]

23. Mitra, T.; Bhattacharya, R. Phytochemicals modulate cancer aggressiveness: A review depicting the anticancer efficacy of dietary polyphenols and their combinations. J. Cell Physiol. 2020. [CrossRef] [PubMed]

24. Xiong, Y.; Hannon, G.J.; Zhang, H.; Casso, D.; Kobayashi, R.; Beach, D. p21 is a universal inhibitor of cyclin kinases. Nature 1993, 366, 701-704. [CrossRef] [PubMed]

25. Conforti, F.; Marrelli, M.; Menichini, F.; Bonesi, M.; Statti, G.; Provenzano, E.; Menichini, F. Natural and synthetic furanocoumarins as treatment for vitiligo and psoriasis. Curr. Drug Ther. 2009, 4, 38-58. [CrossRef]

26. Sumorek-Wiadro, J.; Zając, A.; Maciejczyk, A.; Jakubowicz-Gil, J.; Joanna, S.-W.; Adrian, Z.; Aleksandra, M.; Joanna, J.-G. Furanocoumarins in anticancer therapy-For and against. Fitoterapia 2020, 142, 104492. [CrossRef]

27. Ahmed, S.; Khan, H.; Aschner, M.; Mirzae, H.; Küpeli Akkol, E.; Capasso, R. Anticancer potential of furanocoumarins: Mechanistic and therapeutic aspects. Int. J. Mol. Sci. 2020, 21, 5622. [CrossRef]

28. Marrelli, M.; La Grotteria, S.; Araniti, F.; Conforti, F. Investigation of the potential health benefits as lipase inhibitor and antioxidant of Leopoldia comosa (L.) Parl.: Variability of chemical composition of wild and cultivated bulbs. Plant Foods Hum. Nutr. 2017, 72, 274-279. [CrossRef]

29. Marrelli, M.; Menichini, F.; Conforti, F. A comparative study of Zingiber officinale Roscoe pulp and peel: Phytochemical composition and evaluation of antitumour activity. Nat. Prod. Res. 2015, 29, 2045-2049. [CrossRef]

30. Conforti, F.; Marrelli, M.; Statti, G.; Menichini, F.; Uzunov, D.; Solimene, U.; Menichini, F. Comparative chemical composition and antioxidant activity of Calamintha nepeta (L.) Savi subsp. glandulosa (Req.) Nyman and Calamintha grandiflora (L.) Moench (Labiatae). Nat. Prod. Res. 2012, 26, 91-97.

31. Menichini, G.; Alfano, C.; Marrelli, M.; Toniolo, C.; Provenzano, E.; Statti, G.A.; Nicoletti, M.; Menichini, F.; Conforti, F. Hypericum perforatum L. subsp. perforatum induces inhibition of free radicals and enhanced phototoxicity in human melanoma cells under ultraviolet light. Cell Prolif. 2013, 46, 193-202.

32. Marrelli, M.; Conforti, F.; Formisano, C.; Rigano, D.; Arnold, N.A.; Menichini, F.; Senatore, F. Composition, antibacterial, antioxidant and antiproliferative activities of essential oils from three Origanum species growing wild in Lebanon and Greece. Nat. Prod. Res. 2016, 30, 735-739. [CrossRef]

33. Giordano, F.; Naimo, G.D.; Nigro, A.; Romeo, F.; Paolì, A.; De Amicis, F.; Vivacqua, A.; Morelli, C.; Mauro, L.; Panno, M.L. Valproic acid addresses neuroendocrine differentiation of LNCaP cells and maintains cell survival. Drug Des. Dev. Ther. 2019, 13, 4265-4274. [CrossRef] [PubMed]

34. Conforti, F.; Marrelli, M.; Statti, G.; Menichini, F. Antioxidant and cytotoxic activities of methanolic extract and fractions from Senecio gibbosus subsp. gibbosus (GUSS) DC. Nat. Prod. Res. 2006, 20, 805-812. [CrossRef] [PubMed]

35. Conforti, F.; Loizzo, M.R.; Marrelli, M.; Menichini, F.; Statti, G.A.; Uzunov, D.; Menichini, F. Quantitative determination of Amaryllidaceae alkaloids from Galanthus reginae-olgae subsp. vernalis and in vitro activities relevant for neurodegenerative diseases. Pharm. Biol. 2010, 48, 2-9. [PubMed] 